\title{
GOSPODAROWANIE PRZESTRZENIĄ W ODNOWIE WSI - ZASTOSOWANIE KONCEPCJI MIEJSCA DO ANALIZY PROJEKTÓW ODNOWY WSI
}

Zarys treści Nie tylko termin ,przestrzeń” posiada wiele znaczeń, lecz także pojęcia bezpośrednio z nim powiązane są bogate w różnorodne konotacje. Przestrzeń może być rozumiana zarówno jako abstrakcyjna idea, właściwość materii, środowisko naturalne wykształcone w określony sposób w toku ewolucji lub wreszcie jako wytwór ludzki - antropogeniczny, kulturowy i społeczny (Jałowiecki, Szczepański 2009: 314). Wynika to nie tyle z braku precyzji językowej, ile z pewnych nastawień teoretycznych i filozoficznych, czasem nawet nieuświadomionych i niezwerbalizowanych, stosowanych przez różne środowiska naukowe. Niniejszy artykuł stanowi próbę przybliżenia różnych koncepcji przestrzeni funkcjonujących w naukach społecznych i wyodrębnienia z nich koncepcji miejsca jako „przestrzeni oswojonej” - bogatej w sensy i znaczenia. A to w celu spojrzenia na wybrany projekt zrealizowany w ramach programu Odnowa Wsi w kategoriach przemiany przestrzeni obcej w miejsce oswojone. Powstaje zatem pytanie o sposób „gospodarowania” przestrzenią w Odnowie Wsi, który prowadzi do nadania jej wartości miejsca.

Słowa kluczowe Przestrzeń, miejsce, Odnowa Wsi.

\section{Wprowadzenie}

W ujęciu nie tylko geografii humanistycznej ${ }^{1}$, ale także socjologii, przestrzeń i miejsce są zasadniczymi składnikami ludzkiego świata. Zdaniem P. Pellegrino ,„przestrzeń występuje jednocześnie w wielorakiej roli, jest teatrem, w którym

\footnotetext{
${ }^{1}$ Geografia humanistyczna posługuje się m.in. następującą klasyfikacją odnoszącą się do przestrzeni. Na gruncie literatury przedmiotu wyróżnia się więc przestrzeń pierwotną, która integruje człowieka z jego naturalnym, organicznym środowiskiem; przestrzeń percepcyjną, która nadaje tożsamość jednostce jako osobie; przestrzeń egzystencjalną - pozwalającą człowiekowi przynależeć do określonej grupy społecznej i kulturowej. A także przestrzeń architektoniczną (integrującą doświadczenie i myśli), oraz abstrakcyjną - oznaczającą, że człowiek jest w stanie myśleć zarówno o przestrzeni swojego życia, a także kreować inne przestrzenie logiczne (Jędrzejczyk 2001: 88).
} 
rozgrywają się nasze interakcje, sama jest często przedmiotem tych interakcji, może być ich aktorem, gdy mowa jest o symbolach nierozerwalnie związanych z przestrzenią, $w$ tym zresztą ostatnim znaczeniu może też być specyficzną wartością społeczną” (za: Wódz 1989). Miejsce zaś jest „naiwnym i zmiennym odzwierciedleniem doświadczenia otoczenia przez podmiot" (Passi 1986), będąc jednocześnie pewnym wycinkiem przestrzeni fizycznej, naznaczonym swojskością i emocjonalną treścią. W doświadczeniu życia codziennego przestrzeń i miejsce często nakładają się na siebie, przechodzą jedne w drugie. To, co jest na początku przestrzenią, a więc jest obce i abstrakcyjne, staje się miejscem w miarę poznania i nadawania mu przez człowieka znaczeń. $Z$ drugiej strony pewne miejsca mogą utracić swoje znaczenie i stać się obcymi, przekształcając się w nic nie znaczące dla człowieka przestrzenie. Istotne wydaje się więc ustalenie wzajemnych relacji ${ }^{2}$ między przestrzenią a miejscem (Jędrzejczyk 2001: 86). Humanistyczne podejście do zagadnienia przestrzeni postuluje badać ją wraz z przynależnym do niej „współczynnikiem humanistycznym” (określenie zaczerpnięte od W.I. Thomasa i F. Znanieckiego), to jest tak, jak jest ona doświadczana przez podmioty ludzkie (Jędrzejczyk 2001: 90). Według F. Znanieckiego przestrzeń jest wartością jako element ogólniejszego systemu wartości, w stosunku do którego uzyskuje ona dopiero treść (Znaniecki 1938). Przestrzeń zyskuje przymiotnik „społeczna”, gdyż ludzie przywiązują do niej określone wartości, ale i wytwarzają ją w drodze wzajemnych interakcji.

Taka optyka w niniejszym artykule zostaje wykorzystana do analizy wybranych projektów z zakresu Odnowy Wsi ${ }^{3}$, których pierwotnym celem była odnowa przestrzeni, ale które dodatkowo (na co wskazują narracje mieszkańców wsi) zyskały potencjał w stworzeniu miejsc znaczących i bliskich ich użytkownikom. W ramach działań „odnawiających” wspierano projekty obejmujące: realizację inwestycji w zakresie modernizacji i wyposażenia obiektów pełniących funkcje kulturalne, rekreacyjne i sportowe; odnowę obiektów zabytkowych charakterystycznych dla tradycji budownictwa wiejskiego regionu i ich adaptacji na cele publiczne; modernizację przestrzeni publicznej wsi; publiczną infrastrukturę przyczyniającą się do rozwoju funkcji turystycznych wsi oraz działania związane z promocją regionu (SPO 2004: 82). Wydają się być to przedsięwzięcia ingerujące w przestrzeń wiejską, które niosą dla niej szereg rozmaitych konsekwencji.

\footnotetext{
${ }^{2}$ Miejsce $\mathrm{w}$ powiązaniu z przestrzenią posiada wiele znaczeń, przede wszystkim zaś należy pamiętać, że miejsca są osadzone $\mathrm{w}$ danej przestrzeni. Fenomen miejsca $\mathrm{w}$ takim kontekście, zdaniem E.C. Relpha, można zrozumieć rozpatrując takie własności miejsca, jak: położenie, krajobraz, sens oraz tożsamość (1970: 193-201).

${ }^{3}$ Działanie 2.3 Odnowa wsi oraz zachowanie i ochrona dziedzictwa kulturowego wsi, realizowane w ramach Sektorowego Programu Operacyjnego „,Restrukturyzacja i modernizacja sektora żywnościowego oraz rozwój obszarów wiejskich” na lata 2004-2006.
} 
Zanim jednak zostaną one omówione, należy zapoznać się bardziej szczegółowo z wybranymi koncepcjami przestrzeni i miejsca, które są obecne w geografii społecznej oraz socjologii.

\section{Wybrane koncepcje przestrzeni i miejsca funkcjonujące w naukach społecznych}

Próbę systematyzacji pojęcia ,przestrzeń” w geografii człowieka oparto głównie na dorobku geografii anglojęzycznej i polskiej (Lisowski 2003: 8), uwzględniając w pewnym stopniu także dorobek innych nauk, mających wpływ na kształt geograficznych konceptualizacji przestrzeni, w tym także socjologii. Uporządkowanie koncepcji przestrzeni podejmowano częściej w artykułach aniżeli w pozycjach książkowych (Dziewoński 1965; Welch 1972; Dramowicz 1984; Fliedner 1992; Liszewski 1995, 1997; Wojciechowski 1996; Chojnicki 1999a, 1999b) (za: Lisowski 2003: 8). Zdaniem Z. Chojnickiego (1999a: 85) „Pojęcie przestrzeni ma niezwykle rozległe powiązania i nie da się go explicite zdefiniować w sposób wszechogarniający", a wszelkie klasyfikacje i podziały przestrzeni mają charakter jedynie umowny. Warto jednak przyjrzeć się niektórym z nich. I tak geografowie wyróżniają przestrzeń fizyczną (fizykalną) - stanowiącą zbiór przedmiotów (wraz z uprzedmiotowionym człowiekiem), łącznie z określonym ich położeniem w stosunku do jakiegoś układu odniesienia; niefizyczną (relatywną) - wyznaczoną przez stosunek między człowiekiem a przestrzenią fizyczną; przestrzeń ekologiczną - utożsamianą z obszarem użytkowanym przez jednostki, determinującym ich sposoby życia, potrzeby, zachowania; przestrzeń kulturową - zawierającą w sobie zbiór znaczeń i sensów ułatwiających społeczne trwanie i komunikację jednostek, oraz przestrzeń społeczną - pełniącą istotną rolę w organizacji życia społecznego, w którą wpisane są różnorodne procesy społeczne, ukształtowaną w toku działań ludzkich (Lisowski 2003: 8-10). We współczesnej konceptualizacji przestrzeni społecznej, odnajdujemy podział bezpośrednio nawiązujący do propozycji H. Lefebvre'a (1991), autor ten w ramach owej przestrzeni społecznej wyróżnił przestrzeń abstrakcyjną (przedstawianą) oraz konkretną (czyli tak zwaną interpretację przestrzeni). Z punktu widzenia założeń artykułu, istotniejsze wydaje się przybliżenie pojęcia przestrzeni konkretnej. Jest ona przede wszystkim przestrzenią doświadczaną przez jednostkę w całym bogactwie tego doświadczenia, odwołującą się głównie do emocji, związaną z uczestnictwem jednostki w danej grupie społecznej (Lefebvre 1991: 239-240). To także przestrzeń określona, postrzegana skądś, organiczna, wypełniona, umiejscowiona „gdzieś”, stabilna, doświadczana, bezpieczna, swojska, bliska, konsumowana (Lisowski 2003: 152 za: Yi-Fu Tuan (1987), H. Lefebvre (1991), R.D. Sack (1992), P.J. Taylor (1999). 
Takie ujęcie przestrzeni konkretnej wydaje się być bliskie koncepcji miejsca ${ }^{4}$, która podobnie jak koncepcje przestrzeni, wymyka się jednoznacznym definicjom. Mimo, iż w ostatnich latach zainteresowanie wśród geografów tym tematem wzrosło, nie wypracowano jednego, uniwersalnego i obowiązującego wzorca, zaś podstawy metodologiczno-teoretyczne różnych koncepcji miejsca pochodzą z wielu obszarów wiedzy o człowieku i społeczeństwie (Wójcik 2008: 136). W naukowym znaczeniu, miejsce jest pewną formą abstrakcyjnego myślenia o rzeczywistości w procesie jej poznawania, zaś sam sposób myślenia o kategorii miejsca wyznacza przyjęta koncepcja metodologiczna (we współczesnych badaniach geograficznych mamy do czynienia z dwiema opozycyjnymi orientacjami: scjentystyczną i antyscjentystyczną) (Wójcik 2008: 136 za: Chojnicki 1999). Według tej pierwszej, miejsce jest rozpatrywane jako część przestrzeni, pewne terytorium (obszar), pełniący określone funkcje w organizacji społecznej ${ }^{5}$. W orientacji antyscjentystycznej miejsce ma już wymiar aksjologiczny, a znaczenie miejsc jest różne i zależy od osobistych doświadczeń podmiotów poznających (Jędrzejczyk: 2001). Miejsce jest pewnym wyobrażeniem człowieka o otoczeniu. Geografia humanistyczna, w opozycji do scjentyzmu, przyjmuje metody bezpośredniego, subiektywnego opisu doświadczeń oraz dopuszcza wiedzę opartą na intuicji (Chojnicki 1999), również dzięki inspiracjom fenomenologii socjologicznej. Tak więc prace zarówno geograficzne, jak i socjologiczne ukazują możliwości tkwiące w człowieku jako kreatorze i moderatorze miejsca, a zarazem zwrotny jego potencjał w oddziaływaniu na zachowania i wyobrażenia ludzi (Wójcik 2008: 142). Geografowie szczególnie cenią sobie też dorobek brytyjskiego socjologa A. Giddensa (m.in. teoria strukturacji jest przyczynkiem wielu dyskusji naukowych), dla którego miejsce jest przestrzenią fizyczną, która istnieje jako pewien kontekst społecznych interakcji (spotkania). Miejsca istnieją więc jako teren codziennych, utrwalonych spotkań (Wójcik 2008: 143). Miejsce to tyle, co „ja" i „mój świat”. Należy więc wyraźnie zaznaczyć, iż koncepcja miejsca w takim podejściu jest nierozerwalnie związana z humanistyczną wizją człowieka.

Pogłębioną refleksję na temat funkcji miejsca (na przykładzie miasta) prowadzi A. Suliborski (2001). I tak, funkcja miejsca to jego społeczna rola polegająca na zaspokajaniu pewnej części potrzeb indywidualnych i społecznych.

\footnotetext{
${ }^{4}$ Podstawy filozoficzno-teoretyczne koncepcji przestrzeni kulturowej odnajdujemy w fenomenologii socjologicznej (fenomenologia w ogóle była jednym z nurtów, który bardzo silnie wpłynął na rozwój geografii humanistycznej). Jej przedstawiciel - E. Husserl dążył do znalezienia podstaw wiedzy nie wywodzącej się z zasad scjentyzmu. Taką zasadą, na której powinno opierać się wg tego autora rozumowanie, jest intuicja. Zainteresowanie kieruje się tu zatem na ludzi, dla których świat jest światem zjawiającym się, osądzonym, ocenianym. Chodzi więc o to, z jakim szczególnym sensem i w jaki sposób świat ten jawi się jednostkom, a nie o to, jakim on faktycznie jest (Jędrzejczyk 2001: 26).

${ }^{5}$ Teoretyczno-metodologiczną podstawą opisu i wyjaśniania działalności człowieka w miejscu jest koncepcja systemowa (Wójcik 2008: 137).
} 
Istota funkcji zawiera się w jej czterech atrybutach: formie, eksploatacji, percepcji (postrzeganiu miejsca) oraz znaczeniu (wartości) - te zaś wynikają z przeżyć jednostek, stanowiąc pewien efekt ich skumulowanych doznań emocjonalnych. W wyniku tych właśnie przeżyć (czy to własnych, czy innych, aktualnych czy odległych), miejsce nabiera specyficznego znaczenia (wartości). Cechy te stanowią o jego funkcji znaczenia. Co istotne, dwie ostatnie funkcje miejsca: percepcja i znaczenie, jako te o ładunku typowo społecznym, są uwarunkowane denotującą treścią miejsca, zachodzącymi relacjami pomiędzy danym miejscem a podmiotem oraz jego psychofizycznymi i kulturowymi charakterystykami (Suliborski 2001).

Wobec powyższego należy jeszcze raz podkreślić, iż przestrzeń ma charakter społeczny, jako taka stanowi więc ważną kategorię analityczną socjologii. Na gruncie tej nauki można ją ujmować w sposób czysto metaforyczny (nieposiadającą denotatu materialnego, nie oznaczającą więc żadnego konkretnego miejsca czy obszaru), jako pewien wymiar rzeczywistości społecznej, układ ról i pozycji społecznych, czy na przykład przestrzeń konfliktów (Jałowiecki, Szczepański 2009: 316). Znacznie częściej jednak używa się terminu przestrzeń społeczna w znaczeniu miejsca, wytworzonego przez daną grupę społeczną, któremu nadała ona określone i specyficzne znaczenie (jest więc ujmowana jako przestrzeń społecznie wytworzona). W ujęciu socjologicznym przestrzeń społeczna może być analizowana w wymiarach jej (tamże: 319$)$ :

- percepcji i waloryzacji - kiedy to przestrzeń postrzega się w kategoriach znaczącej, posiadającej określony sens i konotację wartościującą. Człowiek postrzegający (ale i wartościujący) przestrzeń, tworzy jej obrazy za pomocą słów (własnych kryteriów estetycznych, egzystencjalnych, użytkowych czy etycznych), posługując się przy tym różnymi pojęciami. A ponieważ są to zazwyczaj słowa zaczerpnięte z języka potocznego, często mają charakter mglisty, płynny czy mało ostry. W efekcie otrzymuje się opis miejsca z pewnymi elementami oceny wykonany przez podmiot „naznaczający” tą przestrzeń;

- przyswajania - znaczy tyle, co dłuższe bądź krótsze umiejscowienie siebie na jakimś terenie i uznanie go w mniejszym lub większym stopniu za własny, w znaczeniu indywidualnego lub grupowego użytkowania.

Proces percepcji, waloryzacji i przyswajania przestrzeni w konsekwencji przekłada się i na sposoby jej wytwarzania oraz użytkowania, a także na zawłaszczanie przestrzeni przez podmiot (Jałowiecki, Szczepański 2009: 319).

Zaprezentowane koncepcje przestrzeni i miejsca w ujęciu geografii społecznej i socjologii to ujęcia „humanizujące” tę kategorię, gdzie znaczącą rolę przypisuje się jednostce jako podmiotowi poznającemu (aktorowi) użytkującemu daną przestrzeń, który to w toku interakcji, nagromadzonych doświadczeń, intuicji, negocjuje przestrzeń, nadając jej określone sensy i znaczenia, w konsekwencji czyniąc przyjazną i oswojoną. Przytoczone w tej części artykułu ujęcia przestrzeni mają pomóc w zrozumieniu zjawiska „wyodrębniania” się miejsc z przestrzeni, zagospodarowanych dzięki realizacji projektów z zakresu Odnowy Wsi. 


\section{3. „Odnowić” przestrzeń znaczy uczynić ją miejscem Przypadek centrum wsi w Moskwie w gminie Nowosolna}

Odnowa Wsi jako program, w warstwie dosłownej (czyli jak sama nazwa wskazuje), wzorem krajów europejskich, miał przyczynić się do uatrakcyjnienia i podniesienia estetycznej wartości przestrzeni wiejskich, które tego szczególnie wymagały, na które był pomysł i na które udało się uzyskać dofinansowanie. Miał on na celu odnowę i rewitalizację, a czasem po prostu uporządkowanie, a więc jakąkolwiek zmianę przestrzeni, służącą lepszemu jej zagospodarowaniu i szerszemu użytkowaniu przez społeczność lokalną. W centrum zainteresowań badawczych autorki tekstu znalazły się projekty Odnowy Wsi realizowane w województwie łódzkim ${ }^{6} \mathrm{w}$ ramach Sektorowego Programu Operacyjnego „Restrukturyzacja i modernizacja sektora żywnościowego oraz rozwój obszarów wiejskich" na lata 2004-2006, a szczególnie jeden, wdrażany w tej perspektywie: „Zagospodarowanie, uporządkowanie i oznakowanie placu w centrum wsi Moskwa"7, w gminie Nowosolna. Projekt ten stanowił stosunkowo wyraźny przykład na potwierdzenie tez, że niektóre odnawiane przestrzenie mają większą szansę stania się miejscem ważnym społecznie w oczach jego użytkowników niż inne, nawet temu podobne. A tak doświadczane miejsce to lokalna wartość.

Pierwotnym i zarazem podstawowym celem prowadzonych przez autorkę badań (część jakościowa obejmowała m.in. realizację wywiadów swobodnych z mieszkańcami wsi użytkującymi przestrzenie odnowione) było wykazanie funkcji, jakie te projekty spełniały na rzecz zrównoważonego rozwoju obszarów wiejskich. Przy okazji jednak, niezamierzenie, utrwalone narracje ukazały sposoby definiowania, ujmowania, naznaczania „odnawianych” przestrzeni przez

${ }^{6}$ Badania pogłębione zostały przeprowadzone w gminie Nowosolna, która została wybrana do badań w sposób celowy jako gmina najaktywniejsza (tzn. realizująca największą ilość projektów), z całego województwa, w działaniach Odnowy Wsi w czasie finansowania działań w latach 2004-2006.

${ }^{7}$ Według dokumentów programowych (w tym sprawozdania $\mathrm{z}$ realizacji projektów Odnowy Wsi), udostępnionych przez Urząd Marszałkowski w Lodzi (Departament Funduszu Rozwoju Obszarów Wiejskich), projekt ten miał na celu ukształtowanie centrum wsi poprzez: uporządkowanie terenu działki gminnej o powierzchni $1000 \mathrm{~m}^{2}$ (mechaniczne karczowanie drzew oraz średnio gęstych zagajników, oczyszczenie terenu z pozostałości po wykarczowaniu); wykonanie prac ziemnych związanych z plantowaniem terenu działki (ręczne roboty ziemne, ręczne rozścielenie humusu), wykonanie trawnika oraz jego pielęgnacja; przygotowanie ekspozycji głazów narzutowych (uzysk i transport kamienia narzutowego); przygotowanie powierzchni informacji wizualnej o tematyce: podstawowe informacje o sołectwie, podstawowe informacje o otoczeniu sołectwa i atrakcjach turystycznych w jego sąsiedztwie, zakup i montaż tablic informacyjnych.

Projekt zagospodarowania centrum wsi w Moskwie był realizowany w okresie: 19.04.2007-21.12.2007 i opiewał na kwotę: 15400,00 zł. 
ich użytkowników, a więc mieszkańców badanych wsi (czyli zgodnie z terminologią socjologiczną: percepcję i wartościowanie, a ostatecznie przyswajanie tej przestrzeni). Szybko okazało się, że nie wszystkie, ale niektóre z nich posiadały tzw. „potencjał miejsca”. To znaczy jawiły się społeczności lokalnej jako przestrzeń bardziej bliska i znacząca, definiowana pozytywnie, jakby ważniejsza, też częściej przez nią użytkowana. Powstaje zatem pytanie o uwarunkowania kreowania (na skutek wdrażania projektów Odnowy Wsi) przestrzeni o „potencjale miejsca". Należy jednak zaznaczyć, że wszelkie rozważania i wnioski poczynione na podstawie zebranego materiału empirycznego, stanowią jedynie wstęp do dalszych pogłębionych analiz w tym zakresie.

Ogólnie rzecz biorąc, kierunki realizowanych przedsięwzięć Odnowy Wsi pozwalają wyróżnić ich dwie główne grupy (Heffner 2007: 61-62):

1. Proste, charakterystyczne dla fazy inicjalnej początkowego etapu procesu Odnowy Wsi.

2. Kompleksowe w skali wsi, istotne z punktu widzenia rozwoju (głównie ekonomicznego) wsi, podejmowane w fazie zaawansowanej procesu.

Ponieważ program Odnowy Wsi finansowany ze środków SPO 2004-2006 stanowił jedno z pierwszych zetknięć polskich wsi z tematem „odnawiania” przestrzeni wiejskich, analizowane projekty wpisują się w pierwszą, wyodrębnioną powyżej przez autora, grupę. Działania te służyły m.in. zagospodarowaniu przestrzeni wspólnych, nadawaniu walorów użytkowych miejscom zapomnianym i zaniedbanym. Były to głównie przedsięwzięcia o charakterze punktowym, pojedyncze, lecz nie mniej ważne dla procesu Odnowy Wsi, który dla wielu polskich wsi rozpoczął się właśnie w momencie wdrażania SPO 2004-2006. Warto zadać sobie pytanie o to, jakie warunki powinny zostać spełnione, aby dany projekt Odnowy Wsi „,pracował”, był funkcjonalny społecznie i dobrze „gospodarujący przestrzenią"? Literatura przedmiotu oraz praktyka realizacji programu wskazuje na kilka czynników (należy je jednak traktować jako pewne uwarunkowania, a nie czynniki ostatecznie odpowiedzialne za sukces projektu):

1. Korespondowanie $\mathrm{z}$ otoczeniem - projekt nie powinien zaburzać przestrzeni, a pasować do niej, być zgodnym z całościowym charakterem wsi, wpisywać się w jej wnętrza krajobrazowe, powinien być ponadto spójny, ale i estetyczny, przyjazny dla oka, mieć dobry wpływ na otoczenie. Na powyższe składają się następujące cechy projektu: odpowiednia forma fizyczna (kształt, detal, materiał, faktura), ale także lokalizacja, skala realizacji, związki z bliższym lub dalszym otoczeniem;

2. Wpisywanie się projektu w główny kierunek rozwoju miejscowości: projekt powinien wykorzystywać i wzmacniać specyfikę miejsca, bazując na jego zasobach, a nie być oderwaną od całości, pojedynczą inwestycją;

3. Posiadanie walorów użytkowych - projekt powinien być celowy, to znaczy mieć określonych odbiorców, być odpowiedzią na ich realne potrzeby i je zaspokajać, funkcjonować jako użyteczny dla społeczności. 
W swoich pracach (np. Good City Form) K. Lynch (1984), co prawda badacz miast i przestrzeni miejskich, podkreśla, iż precyzując cel planowania i kształtowania przestrzeni, należy zadać sobie przede wszystkim pytanie: „Po co i dla kogo?”; postuluje, aby założenia planistyczne i kierunki rozwoju przestrzeni wyprowadzać z ludzkich działań, aktywności, doświadczeń, wyobrażeń oraz przypisywanych im znaczeń. $Z$ tego wynika, że przestrzeń, która otacza jednostkę jest plastyczna - można ją adoptować, przyswajać, kształtować. W tym procesie przeobrażania przestrzeni, ludzie przypisują określone funkcje, sensy i znaczenia (,naznaczają tę przestrzeń”) wybudowanym świetlicom, zagospodarowanym skwerom, parkom, placom. Powoduje to, że użytkownicy tychże miejsc stale odczytują, najczęściej w sposób nie w pełni świadomy, pewne kody i szyfry semiotyczne przypisane tym miejscom. Codzienne i stałe „odczytywanie” przestrzeni prowadzi do budowania trwałych obrazów, przekonań na temat określonych miejsc. Przykład mogą stanowić poniższe narracje (fragmenty wywiadów swobodnych przeprowadzonych z osobami ważnymi dla procesu odnowy wsi w gminie Nowosolna, a także bezpośrednimi użytkownikami tych przestrzeni):

Sołtys o świetlicy środowiskowej:

Tam (w świetlicy) się odbywały próby, zebrania wiejskie. Funkcje tej świetlicy są bardziej rozszerzone niż na początku. Odbywają się wszelkie projekty prowadzone przez panie z GOPS, różne kursy, spotkania, organizujemy spotkania wigilijne, Dzień Babci i Dziadka, ale przede wszystkim jej główna rola to jest tam teraz świetlica środowiskowa, głównie dla młodzieży, ale nie tylko, dla mieszkańców również. Opiekujemy się kilkoma rodzinami. To miejsce pełni dla nas różne role, jest ważne dla wszystkich mieszkańców, to na pewno.

Sołtys o placu zabaw:

Taki zewnętrzny człowiek, co będzie przychodził - to co dla niego to miejsce znaczy? Jemu jest obojętne, ale nam nie.

Mieszkaniec o centrum wsi w Moskwie:

Tak naprawdę, to nigdzie więcej nic się nie dzieje, tylko wszystko na tym placu... spotkanie na placu... zebranie KGW na placu... wszystkie imprezy, my nie mamy innej sali, taka otwarta świetlica (...) Po prostu może to jest taka moda, że idą ludzie na ten plac, że w sobotę i w niedzielę jest gwar, czy to młodzież, czy dorośli, czy dzieci. Już nie pamiętam czasów, jak ten plac nie istniał... teraz to nasz plac, nasze miejsce do robienia ważnych rzeczy na co dzień i od święta.

Zatrzymawszy się na ostatniej narracji, generalnie rzecz ujmując, place - centra wsi pełnią istotną rolę w życiu społecznym lokalnej społeczności. Wskazuje się m.in. na następujące ich funkcje: organizacyjne, integracyjne, reprezentacyjne, ozdobne, handlowo-usługowe, rekreacyjne czy nawet sportowe (Niedźwiecka-Filipiak 2009: 76-77). Przez centrum wsi należy rozumieć obszar przestrzeni publicznej, o którym mowa w art. 2 w pkt. 6 Ustawy z dnia 27 marca 2003 roku 
o planowaniu i zagospodarowaniu przestrzennym (Dz.U. nr 80, poz. 717, z późn. zm.). Ustawa definiuje obszar przestrzeni publicznej jako obszar o szczególnym znaczeniu dla zaspokojenia potrzeb mieszkańców, poprawy jakości ich życia i sprzyjający nawiązywaniu kontaktów społecznych ze względu na jego położenie oraz cechy funkcjonalno-przestrzenne. Mówi się także, że centra wsi mogą stanowić wyróżnik wsi, szczególnie w tych miejscowościach, w których brak jest elementów charakterystycznych. Lokalizacja placów we wsi jest uwarunkowana głównie układem przestrzennym miejscowości oraz pośrednio ukształtowaniem terenu. W przypadku wsi Moskwa, w gminie Nowosolna, jej układ przestrzenny sprzyjał usytuowaniu centrum wsi w samym środku miejscowości, w której dwa drożne pasma rozwojowe są ułożone względem siebie prostopadle. Dodatkowo w Moskwie nie było świetlicy, kościoła czy też innego obiektu, który mógłby posłużyć za miejsce ważne społecznie.

Społeczność Moskwy bardzo szybko dostrzegła zalety zagospodarowania przestrzeni w centrum wsi na plac (wcześniej była to przestrzeń nieużytku) oraz jego funkcjonalność, zwyczajem mieszkańców stało się bowiem spędzanie wolnego czasu na „placyku” czy „placu czerwonym”. Lokalizacja przyczyniła się do tego, że obiekt chętnie zaakceptowany przez mieszkańców, stał się dla nich miejscem wypoczynku i rekreacji (rutynizacja zachowań), swoistym epicentrum życia społecznego wsi (miejsca interakcji społecznych). A dane miejsce istnieje, kiedy interakcja się powtarza, tzn. ma charakter rutynowych działań. Powtarzalność musi zachodzić w odcinkach czasu i w tej samej przestrzeni. Miejsce wyraża ontologiczne bezpieczeństwo człowieka, które zawiera więź człowieka z przestrzenią, w której żyje (Wójcik 2010: 186-189). Nie sposób wyliczyć wszystkich imprez, wydarzeń tych cyklicznych i tych organizowanych w sposób jednorazowy na placu w Moskwie.

Tak naprawdę, to nigdzie więcej nic się nie dzieje, tylko wszystko na tym placu... spotkanie na placu... zebranie KGW na placu... wszystkie imprezy, my nie mamy innej sali, taka otwarta świetlica

- stwierdziła Przewodnicząca Rady Gminy, mieszkanka wsi. Większość z tych imprez inicjowały spontaniczne pomysły samych mieszkańców, a służyły one integracji, dobrej zabawie, ale przede wszystkim zacieśnianiu więzi oraz budowaniu wzajemnego zaufania. Co ważne, mieszkańcy aktywnie uczestniczyli również w pracach przy budowie i rozbudowie placu, angażując swój czas i energię, wyrażając przez to swój związek z miejscem i odpowiedzialność za nie, budując swoją tożsamość lokalną oraz wzmacniając więzi sąsiedzkie.

Mówiąc o miejscu, M. Wójcik (za: Giddens 2003: 154-157) znajduje wspólną płaszczyznę dla dwóch nauk: socjologii i geografii, przyznając, że badania geograficzne mogą stanowić inspirację dla socjologów w zakresie powiązania przestrzeni z interakcjami społecznymi. Wyjątkowość geografii jako nauki polega na umiejętności łączenia interakcji społecznej z fizycznymi aspektami środowiska. 
Socjologiczne ujęcie miejsca, według A. Giddensa, polega na tym, że jest ono traktowane jako sceneria interakcji, a więc pewną materialną formą stwarzającą podstawy do zaistnienia interakcji społecznej. Miejsce nie może być zatem opisywane wyłącznie w kategoriach materialnej przestrzeni, ale jako pewien kontekst interakcji (spotkania). Miejsce nie istnieje, jeśli nie posiada ono właściwości interakcji, które mają charakter rutynowych czynności. Istnienie miejsc zaś przyczynia się do zachowania trwałości instytucji (np.: społeczności lokalnej, rodziny, grup społecznych i zawodowych) (Giddens 2003: 154-157).

Wyniki badań ${ }^{8}$ przeprowadzonych przez M. Wójcika (2010) pokazują, że znaczenie przypisywane miejscu uwarunkowane jest uczestnikiem i odbiorcą konkretnego miejsca. Na przykładzie centrum wsi w Moskwie właśnie, autor ten wyjaśnia, jak stopień związania emocjonalnego z miejscem wpływa na jego postrzeganie przez poszczególnych aktorów społecznych. Dla różnych grup użytkowników przestrzeń więc ma inne znaczenie:

1. Miejsce jako społecznie ciągły proces - dla „rdzennych” mieszkańców wsi Moskwa, ówczesne skrzyżowanie dróg zawsze stanowiło ważną przestrzeń, choć był to teren niezagospodarowany i jego funkcje znacznie różniły się od aktualnych. Znaczenie tego kawałka przestrzeni umocniło się, kiedy plac został uporządkowany i zagospodarowany na centrum wsi.

2. Miejsce jako doświadczenie nabywane - nowi mieszkańcy, z krótkim stażem, mniej emocjonalnie podchodzą do roli placu w życiu społecznym wspólnoty, rzadziej go też odwiedzają. Lubią to miejsce, ale nie ma ono dla nich tak dużego znaczenia jak dla „rdzennej” społeczności.

3. Miejsce jako przystanek w drodze - tak plac odbierają turyści, dla nich to miejsce o walorach głównie rekreacyjnych, nie przestrzeń interakcji i budowania więzi społecznych.

W związku z powyższym, formułuje się wniosek, że miejsce zyskuje takie znaczenie, jakie nadają mu aktorzy społeczni, potwierdza się zatem fakt, że jest to doświadczenie indywidualne, które może jednak zyskać charakter zbiorowy, ale pod warunkiem, że dla innych jego odbiorców miejsce to też prezentuje jakąś wartość.

Dobrze zrealizowany projekt Odnowy Wsi oswaja przestrzeń, nadając jej charakter miejsca pełnego znaczeń i osobistych kontekstów. Czyni ją ważną dla

\footnotetext{
${ }^{8}$ Autor przeprowadził 12 wywiadów ukierunkowanych z osobami, które z różnych powodów znalazły się na placu w Moskwie w miesiącach: lipiec, sierpień i wrzesień 2009 roku w godz. 12-18. Pytania dotyczyły następujących kwestii: określenia przyczyn i częstotliwości przychodzenia na plac (jako pewnego zrutynizowanego zachowania); określenia roli placu w tworzeniu relacji społecznych; określenia społecznej oceny powstania wiejskiego placu oraz przypisywanych mu znaczeń.
} 
jego odbiorców. Aspekt świadomościowy, czyli stosunek aktorów społecznych do przestrzeni wydaje się zatem nie mniej istotny w procesie Odnowy Wsi, od samego fizycznego przekształcania tej przestrzeni. Należy więc jeszcze raz podkreślić, że proces odnowy wsi w istotny sposób oddziałuje na przestrzeń, zmienia ją, przekształca, „odnawia” (co nie jest równoznaczne tylko z jej poprawieniem, „ubraniem” w nową estetykę), ale także nadaje jej nowe sensy i znaczenia. On ją redefiniuje, zmierzając do ponownego przemyślenia jej funkcji. Tworzenie miejsc zmienia przestrzeń publiczną w obszary wspomagające ich wykorzystanie przez społeczeństwo. Powstają miejsca dające ludziom powód do odpoczynku, do „zatrzymania się”, stania się wręcz częścią otoczenia. Miejsca oferują mnogość doświadczeń i sygnalizują wspólnotę, służą też wzmacnianiu lokalnej tożsamości (Fuhrmann 2013: 78).

\section{Zakończenie}

Proces społecznego wytwarzania przestrzeni, a także przekształcania jej w miejsce wynika z dążenia jednostek do zaspokajania potrzeb, zarówno indywidualnych (własnej integracji, poczucia ciągłości, kształtowania tożsamości), jak i społecznych (potrzeby przynależności, uczestnictwa we wspólnocie, tworzenia więzi). Najważniejsze funkcje miejsc obiektywizują się więc w ich społecznej roli. Koncepcja miejsca została w artykule wykorzystana jako jedna z możliwych propozycji, do zaobserwowania głębszych i bardziej trwałych efektów wdrażania projektów Odnowy Wsi. Niestety, mimo tego, że zdecydowana większość projektów odnawiających zrealizowanych w województwie łódzkim była ukierunkowana na poprawę sfery społecznej (aniżeli gospodarczej czy przyrodniczej, jeśli rozpatrywać efekty programu w kontekście zrównoważonego rozwoju) (Jeziorska-Biel 2015a, 2015b), niewiele odnowionych przestrzeni zafunkcjonowało jako miejsca. Nie jest także powiedziane, że realizacja projektów Odnowy Wsi stanowi warunek konieczny i wystarczający, by z przestrzeni fizycznej wyodrębnić miejsce ważne, pełne znaczeń, sensów, czyli takie, które jest oswojone przez i dla społeczności lokalnej. Może jednak, jeśli przyjmiemy, że jedne przestrzenie są bardziej predestynowane od innych, to znaczy posiadają większy „potencjał miejsca”, objęcie ich programem Odnowy Wsi okaże się skuteczniejsze niż w pozostałych przypadkach. Zaś stworzenie miejsc subiektywnie ważnych dla ich odbiorców powinno być celem i podstawowym efektem wdrażania projektów odnawiających. A takie oswojone przestrzenie zwane miejscami niosą za sobą większe prawdopodobieństwo zaistnienia jako funkcjonalne, użyteczne, spełniające potrzeby mieszkańców, w porównaniu z przestrzeniami nieoswojonymi, obcymi dla ich codziennych użytkowników. 


\section{LITERATURA}

Chojnicki Z., 1999, Podstawy metodologiczne i teoretyczne geografii, Wydawnictwo Naukowe Bogucki, Poznań.

Chojnicki Z., 1999a, Pojęcie odległości w analizie przestrzeni społeczno-ekonomicznej, [w:] Chojnicki Z., Podstawy metodologiczne i teoretyczne geografii, Wydawnictwo Naukowe Bogucki, Poznań.

Chojnicki Z., 1999b, Podstawowe problemy filozoficzne $i$ metodologiczne przestrzeni i czasu, [w:] Chojnicki Z., Podstawy metodologiczne i teoretyczne geografii, Wydawnictwo Naukowe Bogucki, Poznań.

Dramowicz K., 1984, Przestrzeń - wcią̇ nowy stary problem, „Przegląd Zagranicznej Literatury Geograficznej”, 3-4: 25-44.

Dziewoński K., 1965, Zagadnienia integracji analizy kartograficznej i statystycznej w badaniach geograficznych, „Przegląd Geograficzny”, 37(4): 585-597.

Fliedner D., 1992, Antropogeographie, Paradigmenwechsel, kulturelle Evolution, „Geographische Zeitschrift", 80 (1): 1-19.

Fuhrmann Ch., 2013, Przyszłość krajobrazu kulturowego. Strategia projektowania i odnowy obszarów wiejskich, [w:] Niedźwiecka-Filipiak I., Kuriata Z. (red.), Wspótczesny krajobraz wsi. Szanse i zagrożenia, Agencja Wydawnicza „ARGI” s.c., Wrocław.

Giddens A., 2003, Stanowienie społeczeństwa. Zarys teorii strukturacji, Wydawnictwo Zysk i S-ka, Poznań.

Heffner K., 2007, Fundamenty procesu przemian aktywizacyjnych na obszarach wiejskich, [w:] Kłodziński M., Błąd M., Wilczyński R. (red.), Odnowa wsi w integrującej się Europie, IRWiR, Warszawa.

Jałowiecki B., Szczepański M.S., 2009, Miasto i przestrzeń w perspektywie socjologicznej, Wydawnictwo Naukowe Scholar, Warszawa.

Jeziorska-Biel P., 2015a, Odnowa Wsi w gminie Nowosolna $w$ województwie tódzkim, [w:] Psyk-Piotrowska E. (red.), Nowe mechanizmy rozwoju obszarów wiejskich, Wydawnictwo Uniwersytetu Łódzkiego, Łódź.

Jeziorska-Biel P., 2015b, The „Rural Renewal” Programme as a mechanism of promoting sustainable development of municipalities in Poland example of the Lodz Region, [w:] Zajda K., Michalska S. (red.), Young Researchers and the Problems of Polish Rural Areas, University of Łódź Press, Łódź.

Jędrzejczyk D., 2001, Wprowadzenie do geografii humanistycznej, Wydział Geografii i Studiów Regionalnych UW, Warszawa.

Lefebvre H., 1991, The producion of space, Blackwell, Oxford-Cambridge MA.

Lisowski A., 2003, Koncepcje przestrzeni w geografii człowieka, Wydział Geografii i Studiów Regionalnych UW, Warszawa.

Liszewski S., 1995, Przestrzeń turystyczna, „Turyzm”, 5 (2): 87-103.

Liszewski S., 1997, Przestrzeń miejska i jej organizacja, [w:] Domański B. (red.), Geografia, czlowiek, gospodarka, IG UJ, Kraków: 55-66.

Lynch K., 1984, Good City Form, Massachusetts Institute of Technology, MIT Press, Cambridge.

Niedźwiecka-Filipiak I., 2009, Wyróżniki krajobrazu i architektury wsi Polski południowo-zachodniej, Wydawnictwo Uniwersytetu Przyrodniczego we Wrocławiu, Wrocław. 
Passi A., 1986, The institutionalization of regions: a theoretical framework for understanding the emergence of regions and the constitution of regional identity, „Fennia”, 164 (1): 105-146.

Relph E.C., 1970, An inquiry into the relations between phenomenology and geography, „Canadian Geographer”, 14.

Sack R.D., 1992, Place, modernity, and the consumer's world, Johns Hopkins University Press, Baltimore, London.

Sektorowy Program Operacyjny „Restrukturyzacja i modernizacja sektora żywnościowego oraz rozwój obszarów wiejskich” na lata 2004-2006, 2004.

Suliborski A., 2001, Funkcje i struktura funkcjonalna miast. Studia teoretyczno-empiryczne, Uniwersytet Łódzki, Łódź.

Taylor P.J., 1999, Places, spaces and Macy's: place-space tensions in the political geography of modernities, „Progress in Human Geography”, 23: 7-26.

Tuan Yi-Fu, 1987, Przestrzeń i miejsce, Państwowy Instytut Wydawniczy, Warszawa.

Ustawa z dnia 27 marca 2003 roku o planowaniu i zagospodarowaniu przestrzennym (Dz.U. 2003, nr 80, poz. 717, z późn. zm.).

Welch R.V., 1972, Conflict, apparent and real: A review of concepts of space in geography, „New Zealand Geographer”, 34(1): 24-30.

Wojciechowski K.H., 1996, Przestrzeń i geografia, „Rzeki”, 5: 161-179.

Wódz J., 1989, Przestrzeń odniesienia - kilka propozycji metodologicznych, [w:] Wódz J. (red.), Przestrzeń znaczaca. Studia socjologiczne, Śląski Instytut Naukowy, Katowice.

Wójcik M., 2008, Miejsce człowieka na Ziemi - refleksje odnoszące się do geograficznego namystu nad czasem, [w:] Maik W., Rembowska K., Suliborski A. (red.), Terytorium, region, miejsce - czas i przestrzeń w geografii. Podstawowe idee i koncepcje w geografii, t. 4, Instytut Geografii i Gospodarki Przestrzennej WSG w Bydgoszczy, Zakład Geografii Społecznej i Studiów Regionalnych UŁ w Łodzi, Bydgoszcz.

Wójcik M., 2010, Struktura i działanie - społeczno-geograficzna interpretacja oddziaływania funduszy Unii Europejskiej na przykładzie programu „,Odnowa Wsi”, [w:] Kacprzak E., Kołodziejczak A. (red.), Rola środków Unii Europejskiej, „Studia Obszarów Wiejskich”, 24, Wydawnictwo „Bernardinum” Sp. z o.o., Warszawa.

Znaniecki F., 1938, Socjologiczne podstawy ekologii ludzkiej, „Ruch Prawniczy, Ekonomiczny i Socjologiczny", 1.

\section{MANAGEMENT OF SPACE IN THE RURAL RENEWAL PROGRAMME - THE APPLICATION OF THE CONCEPT OF SPACE FOR THE ANALYSIS OF PROJECTS RURAL RENEWAL}

Abstract Not only is the term „space” has many meanings, but also the concepts directly linked to it, and has a lot of connotations. The space is both abstract idea, a property of matter, the environment created in a certain way in the course of evolution, there is finally a product of human anthropogenic, cultural and social (Jałowiecki, Szczepański 2009: 314). This is due not so much from the lack of precision of language, how much of certain attitudes of theoretical and philosophical, sometimes even unconscious and unnamed used by various researches. This article is an attempt to present different concepts operating in 
the social sciences, in order to extract from them the concept of tamed space - has a lot of meanings and significances. And this is to look at the project selected under the Rural Renewal Programme in terms of transforming foreign space into tamed. So the question is how to „manage" space in the Rural Renewal Programme, which leads to create place full of values.

Keywords Space, place, Rural Renewal Programme.

Dr Pamela Jeziorska-Biel

Katedra Geografii Regionalnej i Społecznej

Wydział Nauk Geograficznych

Uniwersytet Łódzki

e-mail: pamela.jeziorska@geo.uni.lodz.pl 